in vivo $33: 1411-1420(2019)$

doi:10.21873/invivo.11618

Review

\title{
A Review of Hepatocellular Carcinoma in Elderly Patients Focused on Management and Outcomes
}

\author{
EUNAE $\mathrm{CHO}^{1 *}$, HYUN A. CHO ${ }^{*}$, CHUNG HWAN JUN ${ }^{1}$, HEE JOON KIM ${ }^{2}$, \\ SUNG BUM $\mathrm{CHO}^{1}$ and SUNG KYU CHOI ${ }^{1}$ \\ ${ }^{1}$ Division of Gastroenterology and Hepatology, Department of Internal Medicine, \\ Chonnam National University Medical School, Gwanjgu, Republic of Korea; \\ ${ }^{2}$ Department Surgery, Chonnam National University Medical School, Gwanjgu, Republic of Korea
}

\begin{abstract}
Recent studies report a significant age-specific increase in hepatocellular carcinoma (HCC) development among persons over 75 years old. Therefore, there is an urgent need to determine the optimal treatment strategy in elderly patients with HCC. This systemic review examines the clinical characteristics, efficacy, and safety of first-line treatment modalities. The literature was searched regarding epidemiology and clinical outcomes in elderly patients (age $\geq 75$ years) undergoing first-line treatment for HCC. Causative or comorbid conditions of HCC in elderly patients differed from those in younger patients. Radiofrequency ablation may be effective and safe in early stages. Surgical resection may also be feasible in the early stages for selected patients. Transarterial chemoembolization may be safe and effective for intermediate $\mathrm{HCC}$, and sorafenib may be feasible in elderly patients with advanced HCC. Prospective randomized trials are needed to establish the treatment strategy for elderly patients with HCC.
\end{abstract}

This article is freely accessible online.

*These Authors contributed equally to this study.

Correspondence to: Chung Hwan Jun, MD, Department of Gastroenterology, Chonnam National University Hospital, 42 Jaebong-ro, Donggu, Gwangju 501-757, Republic of Korea. Tel: +82 622206296, Fax: +82 622208578, e-mail: estevanj@naver.com and Hee Joon Kim, MD, Department of Surgery, Chonnam National University Hospital, 42 Jaebong-ro, Donggu, Gwangju 501-757, Republic of Korea. Tel: +82 622206296, Fax: +82 622208578 , e-mail:heejoonkim@jnu.ac.kr

Key Words: Hepatocellular carcinoma, elderly, treatment, prognosis, hepatitis B infection, review.
Due to progress in medical technology and healthcare services, the world's population is aging, and this has brought an increase in cancer prevalence and cancer-related mortality (1). Hepatocellular carcinoma (HCC) is the fifth most common cancer and the second most frequent cause of cancer-related mortality worldwide (2). It is well accepted that aging itself is a risk factor for the development of HCC (3). Recent studies from the USA, the UK, and Japan report a significant age-specific increase in HCC development among persons over 75 years old (4).

Categorizing patients with HCC has been met with some challenges, as the definition of the elderly population has changed over time (5). The United Nations agreed that the term elderly refers to people over 65 years, and previous studies used 65 years as the cut-off for the definition of 'elderly' (6). The government of Japan divides the elderly into two groups: The first elderly stage $(<75$ years) and the second elderly stage ( $\geq 75$ years) (7). More recent studies use 75 years as the threshold for the elderly (8-10). Therefore, 75 years of age may be a more appropriate threshold for the definition of elderly.

According to the life expectancy data from South Korea, a 75-year-old man can expect to live an additional 10.8 years, and a 75-year-old woman can expect to live an additional 12.4 years (www.kosis.kr). Hence, it is very likely for an elderly patient to have a life expectancy of an additional 10 or more years. Therefore, there is an urgent need to develop a new treatment strategy for elderly patients with HCC.

Elderly patients are considered 'fragile' due to their comorbidities and altered drug metabolism, and they are considered more vulnerable to the complications of chemotherapy or surgical treatment $(8,11)$. Therefore, there is a tendency to choose locoregional therapies rather than surgical treatment and supportive care rather than active treatments for 
elderly patients with HCC, which may contribute to their increased mortality compared to younger patients (12).

However, data regarding the efficacy and safety of surgical treatments, locoregional treatments, and chemotherapy for elderly patients with HCC are limited, and current treatment guidelines for HCC do not suggest separate treatment guidelines for older age groups. In general, liver transplantation is not usually recommended when the recipient is over 70 years old because of increased mortality (13). Therefore, this review addresses the clinical characteristics, efficacy, and safety of the various first-line treatment modalities other than liver transplantation for elderly patients over 75 years with HCC.

\section{Data Search}

PubMed, EMBASE, and Web of Science databases were searched from March 2010 to March 2019 for literature on studies examining epidemiology and comparison of clinical outcomes in elderly patients (age $\geq 75$ years) undergoing surgery, locoregional therapies, and systemic therapy as firstline treatments for HCC. We included published comparative studies reporting extractable data for survival outcomes for elderly and non-elderly patients with HCC who underwent hepatic resection, locoregional treatments, and systemic therapy for patients aged 75 years and above. All studies were observational and were either prospective or retrospective in design. Case reports and editorials were excluded.

\section{Clinical Characteristics of HCC in Elderly Patients}

Some distinct clinical characteristics among elderly patients with HCC were identified (Table I). Firstly, they were more likely to have hepatitis $\mathrm{C}$ virus (HCV) infection (14). Most hepatitis $\mathrm{B}$ virus (HBV) infections occur through vertical transmission and resul in HCC development at 50-60 years of age. However, HCV infection generally occurs later in adulthood. Therefore, HCV-related HCC usually occurs approximately 10 years later than HBV-related HCC (3). Secondly, there were more women among the elderly patients with HCC, possibly because of their longer life expectancy (15). Thirdly, elderly patients with HCC were more likely to be negative for both $\mathrm{HBV}$ and $\mathrm{HCV}$ infection (16). This finding may be associated with the increased incidence of nonalcoholic steatohepatitis (NASH)-related HCC among elderly patients (10). NASH-related HCC is diagnosed later in life than HBV- or HCV-related HCC (17). Fourthly, elderly patients with HCC had less liver tissue fibrosis than younger patients (18). There was also a connection between aging and chromosomal changes within the liver. Aging was associated with shortening of the telomeres in the liver (19) and aberrant DNA methylation (17). These changes can cause carcinogenesis, suggesting that aging itself might be a risk
Table I. Different characteristics of hepatocellular carcinoma (HCC) between young and elderly patients.

\begin{tabular}{lcc}
\hline Characteristic & Young & Elderly \\
\hline Etiology & HBV & HCV, NASH \\
Gender difference & Male predominant & Female predominant \\
Background liver fibrosis & More severe & Less severe \\
Aberrant DNA methylation & Less & More \\
HCC nodules & Multi-nodular & Pauci-nodular \\
Vessel invasion & More & Less \\
Differentiation & Poorly differentiated & Well-differentiated \\
\hline
\end{tabular}

DNA: Deoxyribonucleic acid; HBV: hepatitis B virus; $\mathrm{HCV}$ : hepatitis $\mathrm{C}$ virus; NASH: non-alcoholic steatohepatitis.

factor for HCC development. Finally, elderly patients with HCC had fewer HCC nodules than younger patients $(20,21)$. Multi-centric hepatic carcinogenesis is associated with advanced hepatic fibrosis (22), and less fibrosis of the background liver in the elderly may explain this observation. However, the size of HCC nodules in elderly patients was larger than that found in younger patients (23). This finding is probably associated with the absence of regular $\mathrm{HCC}$ surveillance in patients without risk factors such as HBV or $\mathrm{HCV}$ infection. Additionally, tumors in elderly patients tend to be more encapsulated, well-differentiated, and associated with less vascular invasion (3).

\section{Rationale for Treatment}

Controversy exists over whether active treatments are suitable for elderly patients, considering the comorbidities that they often present with. Current first-line treatments for HCC include surgical resection, radiofrequency ablation (RFA), percutaneous ethanol injection therapy (PEIT), microwave ablation, liver transplantation, transarterial chemoembolization (TACE), transarterial radioembolization, targeted therapy, and radiotherapy. Most studies evaluating the clinical outcomes of these treatments in elderly patients with HCC show conflicting results and are limited by small sample sizes $(12,24)$. While some investigators reported poorer survival in elderly patients (25), others reported improved survival after active treatments and suggested active treatment itself was an independent predictor of better outcome, irrespective of age (26). Therefore, restricting treatments based on only age cannot be justified.

\section{Treatment Methods}

\section{Curative therapy}

Surgical resection. Surgical resection is considered the mainstay curative HCC treatment, leading to the best 
Cho et al: Hepatocellular Carcinoma in the Elderly (Review)

Table II. Summary of surgical resection data in elderly $(e)$ and young $(y)$ patients with hepatocellular carcinoma (all studies were retrospective).

\begin{tabular}{|c|c|c|c|c|c|c|c|}
\hline $\begin{array}{l}\text { Year/Author } \\
\text { (Ref) }\end{array}$ & $\begin{array}{l}\text { Definition } \\
\text { of elderly }\end{array}$ & $\begin{array}{l}\text { No. of } \\
\text { patients }\end{array}$ & $\begin{array}{l}\text { Overall } \\
\text { survival }\end{array}$ & $\begin{array}{l}\text { DFS/ } \\
\text { RFS }\end{array}$ & $\begin{array}{l}\text { Postop. stay } \\
\text { (days) }\end{array}$ & $\begin{array}{c}\text { Postop. } \\
\text { complications* }\end{array}$ & $\begin{array}{c}\text { Op. } \\
\text { mortality }\end{array}$ \\
\hline $\begin{array}{l}2010 \text { Tsujita } \\
\text { et al. (1) }\end{array}$ & $\geq 75$ Years & $\begin{array}{l}\text { Y: } 88 \\
\text { E: } 33\end{array}$ & $\begin{array}{l}\text { 3-Year, } p=0.51 \\
\text { Y: } 83 \% \\
\text { E: } 73 \%\end{array}$ & $\begin{array}{c}\text { 3-Year DFS, } p=0.88 \\
\text { Y: } 35 \% \\
\text { E: } 38 \%\end{array}$ & $\begin{array}{c}p=0.11 \\
Y: 17 \pm 14 \\
E: 13 \pm 4\end{array}$ & $\begin{array}{l}p>0.05 \\
\text { Y: } 21.6 \% \\
\text { E: } 18.2 \%\end{array}$ & $\begin{array}{l}p=0.58 \\
\text { Y: } 1 \% \\
\text { E: } 0 \%\end{array}$ \\
\hline $\begin{array}{l}2012 \text { Yamada } \\
\text { et al. ( } 2)\end{array}$ & $\geq 80$ Years & $\begin{array}{l}\text { Y: } 267 \\
\text { E: } 11\end{array}$ & $\begin{array}{c}\text { 5-Year, } p=0.06 \\
\text { Y: } 43 \% \\
\text { E: } 26 \%\end{array}$ & $\begin{array}{l}\text { No significant } \\
\text { difference } \\
(p=0.68)\end{array}$ & N/A & $\begin{array}{c}\text { Overall, } p>0.05 \\
\text { Y: } 43.8 \%, \text { E: } 36.4 \% \\
\text { Severe, } p=0.49 \\
\text { Y: } 5.6 \%, \text { E: } 9.1 \%\end{array}$ & $\begin{array}{l}\text { Y: } 0 \% \\
\text { E: } 0 \%\end{array}$ \\
\hline $\begin{array}{l}2013 \text { Nishgawa } \\
\text { et al. (3) }\end{array}$ & $\geq 75$ Years & $\begin{array}{l}\text { Y: } 206 \\
\text { E: } 92\end{array}$ & $\begin{array}{c}\text { 1/3/5-Year, } p=0.188 \\
\text { Y: } 91 \% / 77.5 \% / 64.4 \% \\
\text { E: } 90 \% / 73.3 \% / 43 \%\end{array}$ & $\begin{array}{c}1 / 3 / 5-\text { Year RFS, } p=0.634 \\
\text { Y: } 6.3 \% / 38.8 \% / 22.2 \% \\
\text { E: } 66.3 \% / 38.8 \% / 26.2 \%\end{array}$ & $\begin{array}{c}p=0.765 \\
\text { Y: } 17.2 \pm 13.3 \\
\text { E: } 17.7 \pm 17.7\end{array}$ & $\begin{array}{c}\geq \mathrm{Gr} 2, p=0.999 \\
\mathrm{Y}: 15.5 \%, \mathrm{E}: 16.3 \%\end{array}$ & N/A \\
\hline $\begin{array}{l}2014 \text { Ueno } \\
\text { et al. (4) }\end{array}$ & $\geq 75$ Years & $\begin{array}{l}\text { Y: } 186 \\
\text { E: } 66\end{array}$ & $\mathrm{~N} / \mathrm{A}, p=0.77$ & N/A & $\begin{array}{l}\text { Y: } 13 \text { (11-18 IQR) } \\
\text { E: } 12 \text { (11-18 IQR) }\end{array}$ & $\begin{array}{c}\geq \mathrm{Gr} 3, p=0.23 \\
\mathrm{Y}: 18.8 \%, \mathrm{E}: 25 \%\end{array}$ & $\begin{array}{l}\text { Y: } 1.1 \% \\
\text { E: } 0 \%\end{array}$ \\
\hline $\begin{array}{l}2015 \text { Kishida } \\
\text { et al. (5) }\end{array}$ & $\geq 75$ Years & $\begin{array}{l}\text { Y: } 82 \\
\text { E: } 22\end{array}$ & N/A & $\begin{array}{c}\text { 5-Year DFS, } p=0.80 \\
\text { Y: } 33 \% \\
\text { E: } 25 \%\end{array}$ & $\begin{array}{c}p=0.33 \\
\text { Y: } 15(11-21 \mathrm{IQR}) \\
\text { E: } 16(12-25 \mathrm{IQR})\end{array}$ & $\begin{array}{l}\text { Overall, } p=0.11 \\
\text { Y: } 28 \%, \mathrm{E}: 59 \% \\
\geq \mathrm{Gr} 3 \mathrm{a}, p=0.006 \\
\text { Y: } 15 \%, \mathrm{E}: 41 \%\end{array}$ & $\begin{array}{c}\text { 30-Day } \\
p>0.99 \\
\text { Y: } 1 \% \\
\text { E: } 0 \% \\
\text { In hospital, } \\
p=0.2 \\
\text { Y: } 2 \% \\
\text { E: } 9 \%\end{array}$ \\
\hline $\begin{array}{l}2017 \text { Santam- } \\
\text { brogio et al. (6) }\end{array}$ & $\geq 75$ Years & $\begin{array}{l}\text { Y: } 115 \\
\text { E: } 53\end{array}$ & $\begin{array}{c}3 / 5 \text {-Year, } p=0.024 \\
\text { Y: } 82 \% / 60 \% \\
\text { E: } 65 \% / 46 \%\end{array}$ & $\begin{array}{c}3 / 5 \text {-Year RFS, } p=0.099 \\
\text { Y: } 57 \% / 35 \% \\
\text { E: } 47 \% / 22 \%\end{array}$ & $\begin{array}{c}p=0.538 \\
\text { Y: } 8.7 \pm 4.6 \\
\text { E: } 9.2 \pm 5.5\end{array}$ & $\begin{array}{l}\text { Overall, } p=0.193 \\
\text { Y: } 34.8 \%, \mathrm{E}: 45.3 \% \text {; } \\
\geq \mathrm{Gr} 2, p=0.017 \\
\mathrm{Y}: 17.4 \%, \mathrm{E}: 33.9 \%\end{array}$ & $\begin{array}{l}\text { 90-Day, } \\
p=0.137 \\
\text { Y: } 2.6 \% \\
\text { E: } 7.5 \%\end{array}$ \\
\hline $\begin{array}{l}2018 \text { Okamura } \\
\text { et al. (7) (PSM) }\end{array}$ & $\geq 75$ Years & $\begin{array}{l}\text { Y: } 310 \\
\text { E: } 111 \\
\text { (Y: } 70 \\
\text { E: } 70)\end{array}$ & $\begin{array}{c}\text { 3/5-Year, } p=0.306 \\
\text { Y: } 77.4 \% / 71.9 \% \\
\text { E: } 77.7 \% / 59 \%)\end{array}$ & $\begin{array}{c}\text { 3/5-Year DFS, } p=0.773 \\
\text { Y: } 34.7 \% / 23.4 \% \\
\text { E: } 39.9 \% / 16 \%\end{array}$ & $\begin{array}{c}p=0.339 \\
\mathrm{Y}: 11(3-70) \\
\text { E: } 11(4-188) \\
p=0.164 \\
\mathrm{Y}: 12(6-61) \\
\text { E: } 11(4-82)\end{array}$ & $\begin{array}{c}\geq \mathrm{Gr} 1, p=0.232 \\
\mathrm{Y}: 29.4 \%, \mathrm{E}: 36 \% \\
(\mathrm{Y}: 31.4 \% \\
\mathrm{E}: 41.4, p=0.292)^{\#} \\
\geq \mathrm{Gr} 3, p=0.015 \\
\mathrm{Y}: 11 \%, \mathrm{E}: 20.7 \% \\
(\mathrm{Y}: 12 \%, \mathrm{E}: 14 \% \\
p=0.828)^{\#}\end{array}$ & $\begin{array}{l}p>0.99 \\
\text { Y: } 1.4 \% \\
\text { E: } 0 \%\end{array}$ \\
\hline $\begin{array}{l}2019 \mathrm{Wu} \\
\text { et al. }(8)\end{array}$ & $\geq 85$ Years & $\begin{array}{l}\text { Y: } 1858 \\
\text { E: } 31\end{array}$ & $\begin{array}{l}p=0.086 \\
Y: 35.5 \% \\
E: 43.5 \%\end{array}$ & $\begin{array}{c}\text { 5-Year DFS, } p=0.163 \\
\text { Y: } 22.6 \% \\
\text { E: } 29.7 \%\end{array}$ & $\begin{array}{l}p=0.001 \\
\text { Y: } 10(7-81) \\
\text { E: } 18(8-46)\end{array}$ & $\begin{array}{c}\text { Overall, } p=0.834 \\
\text { Y: } 19.4 \%, \mathrm{E}: 22.6 \% \\
\geq \mathrm{Gr} 3 \\
\text { Y: } 14.7 \%, \mathrm{E}: 12.9 \%\end{array}$ & $\begin{array}{c}\text { 90-Day, } \\
p>0.99 \\
\text { Y: } 0.91 \% \\
\text { E: } 0 \%\end{array}$ \\
\hline
\end{tabular}

DFS: Disease-free survival; Gr: grade; IQR: interquartile range; N/A: not available; Op.: operative; RFS: recurrence-free survival. *Clavien-Dindo. \#After propensity matching.

outcomes in well-selected patients. Surgical resection is generally indicated for patients with Barcelona-Clinic Liver Cancer (BCLC) stage 0-A HCC with preserved hepatic function and no portal hypertension. In well-selected candidates, the 5-year survival rate is $60-80 \%$, and surgeryrelated mortality occurs in fewer than $3 \%$ of patients (27).

For many years, elderly patients have been considered unfit for surgery due to the increased frequency of comorbidities. However, advances in surgical techniques and postoperative management have made surgical resection in elderly patients safe and feasible. Many recent studies agree that age itself does not have an adverse effect on surgical outcomes (Table II) $(8,9,28-33)$.
Indeed, higher frequencies of comorbidities such as diabetes, hypertension, cerebrovascular disease, and cardiovascular disease were observed in studies comparing surgical resection of elderly versus young patients with HCC $(8,9,29-31,33)$. However, postoperative complications were not significantly different among younger and elderly patients $(8,9,28-33)$. Although some studies reported higher rates of Clavien- Dindo grade 2, 3, or higher postoperative complications among elderly patients $(31,32)$, this finding was not consistent among the included studies (9, 28-30). Additionally, the duration of the postoperative hospital stay was not statistically longer in elderly patients $(8,9,28-32)$, except in one study (33); however, the definition of elderly 
in vivo $33: 1411-1420(2019)$

Table III. Summary of radiofrequency ablation data in elderly $(E)$ and young $(Y)$ patients with hepatocellular carcinoma.

\begin{tabular}{|c|c|c|c|c|c|c|c|}
\hline Year/author & $\begin{array}{l}\text { Definition of } \\
\text { elderly }\end{array}$ & $\begin{array}{l}\text { No. of } \\
\text { patients }\end{array}$ & $\begin{array}{l}\text { Child-Pugh } \\
\text { class A }\end{array}$ & $\begin{array}{c}\text { Overall } \\
\text { survival }\end{array}$ & $\begin{array}{c}\text { Local } \\
\text { progression }\end{array}$ & Morbidity & Mortality \\
\hline $\begin{array}{l}2010 \text { Takahashi } \\
\text { et al. (9) }\end{array}$ & $\geq 75$ Years & $\begin{array}{l}\text { Y: } 354 \\
\text { E: } 107\end{array}$ & $\begin{array}{c}\text { Y: } 72 \% \\
\text { E: } 78.5 \%\end{array}$ & $\begin{array}{c}3 / 5 \text {-Year, } p=0.824 \\
\text { Y: } 80 \% / 63 \% \\
\text { E: } 82 \% / 61 \%\end{array}$ & $\begin{array}{c}1 / 3-\text { Year, } p=0.932 \\
\text { Y: } 8 \% / 12 \% \\
\text { E: } 6 \% / 14 \%\end{array}$ & $\begin{array}{c}\text { Major/minor } \mathrm{Cx} ., \mathrm{p}>0.05 \\
\text { Y: } 3.7 \% / 2 \% \\
\text { E: } 2.8 \% / 1.9 \%\end{array}$ & $\begin{array}{l}\text { Y: } 0 \% \\
\text { E: } 0 \%\end{array}$ \\
\hline $\begin{array}{l}2010 \text { Hiraoka } \\
\text { et al. (10) }\end{array}$ & $\geq 75$ Years & $\begin{array}{l}\text { Y: } 143 \\
\text { E: } 63\end{array}$ & $\begin{array}{l}\text { Y: } 74.8 \% \\
\text { E: } 69.8 \%\end{array}$ & $\begin{array}{c}\text { 1/3/5-Year, } p=0.143 \\
\text { Y: } 93.2 \% / 78.3 \% / 57.5 \% \\
\text { E: } 91.7 \% / 82.5 \% / 49.7 \%\end{array}$ & $\mathrm{~N} / \mathrm{A}, p=0.143$ & N/A & $\mathrm{N} / \mathrm{A}$ \\
\hline $\begin{array}{l}2012 \text { Nishikawa } \\
\text { et al. (11) }\end{array}$ & $\geq 75$ Years & $\begin{array}{l}\text { Y: } 238 \\
\text { E: } 130\end{array}$ & $\begin{array}{l}\text { Y: } 61 \% \\
\text { E: } 67 \%\end{array}$ & $\begin{array}{c}1 / 3-\text { Year, } p=0.001 \\
\text { Y: } 97.6 \% / 83.7 \% \\
\text { E: } 90 \% / 64.1 \%\end{array}$ & $\begin{array}{c}1 / 3 \text {-Year, } p=0.002 \\
\text { Y: } 8.3 \% / 26.3 \% \\
\text { E: } 15 \% / 43 \%\end{array}$ & $\begin{array}{c}\text { Major Cx. } p=0.670 \\
\text { Hospital stay, } p=0.807 \\
\text { Y: } 13.5 \pm 6.6 \\
\text { E: } 13.7 \pm 5.6\end{array}$ & $\begin{array}{l}\text { Y: } 0 \% \\
\text { E: } 0 \%\end{array}$ \\
\hline
\end{tabular}

Cx.: Complication; N/A: not available.

in that study was 85 years or older. Furthermore, postoperative mortality (in-hospital, 30-day, or 90-day) did not differ significantly between elderly and younger patients $(8,9,28-33)$.

Data regarding the overall (OS), disease-free (DFS), and recurrence-free (RFS) survival are also promising. Most studies reported similar 3-or 5-year OS rates for younger and elderly patients with $\operatorname{HCC}(8,9,28,29,31-33)$. Wu et al. compared the OS between patients aged $\geq 85$ years who underwent surgical treatment compared to those that refused surgical treatment. All patients had surgically resectable HCC. In this study, the OS rate of the patients who underwent surgical treatment was significantly higher than that of those who refused to undergo surgery $(35.5 \%$ vs. $0 \%$, $p=0.001$ ) (33). DFS and RFS were also found to be similar for younger and elderly patients $(8,9,28,29,31-33)$.

However, these studies were all retrospective in nature, and selection bias was observed; for example, data on surgical resection performed on patients with early-stage HCC and surgery performed on low-risk patients were not excluded. Therefore, large, prospective, randomized studies are warranted for the evaluation of the efficacy and safety of surgical resection in elderly patients with HCC.

In summary, surgical resection may be feasible in highly selected elderly patients with HCC, and advanced age itself should not be a contraindication for surgery. However, postoperative complications of Clavien-Dindo grade 2 or higher may be observed more frequently among elderly patients. Therefore, a comprehensive oncogeriatric assessment is critical before surgery in elderly patients with HCC.

Radiofrequency ablation. RFA, a curative treatment for $\mathrm{HCC}$, is one of the most commonly performed hyperthermal treatment options. This technique induces coagulative necrosis of the tumor after thermal injury (heating of tissue to $60-100^{\circ} \mathrm{C}$ ) using an electrical current (34).
In a large study reporting 10-year outcomes after RFA in 1,170 patients with primary HCC, RFA seemed to be locally curative for HCC, resulting in survival for as long as 10 years, and was safe (35).

Several studies have compared the efficacies of RFA and surgical resection. Chen et al. reported that the 4-year OS rates after RFA and surgical resection were $67.9 \%$ and $64 \%$, respectively (36). Conversely, in another randomized controlled study comparing RFA and surgical resection in HCC patients who met the Milan criteria, surgical resection provided better survival and a lower recurrence rate than RFA (37).

Given that elderly patients generally have more comorbidities, they may be poorer candidates for surgery. Therefore, RFA may be more feasible than surgical resection in elderly patients. Several studies have reported the efficacy and safety of RFA in elderly patients (Table III). Takahashi et al. (11) and Hiraoka et al. (38) reported similar 3- and 5year OS rates between elderly and younger patients $(11,38)$. Conversely, Nishikawa et al. reported that the 1- and 3-year OS rates after RFA were significantly better in younger patients (39). Data regarding local progression were also conflicting. One study showed similar 1- and 3-year local progression rates between younger and elderly patients $(p=0.932)(11)$, whereas in another study, elderly patients had more frequent local progression $(p=0.002)$ (39). However, RFA-associated complication rates and duration of hospital stay were similar in elderly and younger patients, and no RFA-associated mortality was observed in these studies $(11,38,39)$.

In conclusion, RFA is a safe and effective treatment modality for elderly patients with HCC, especially when surgical resection is not feasible.

Percutaneous ethanol injection therapy. Before the advent of RFA, PEIT was the most widely performed ablative therapy 
Cho et al: Hepatocellular Carcinoma in the Elderly (Review)

Table IV. Summary of transarterial chemoembolization data in elderly $(E)$ and young $(Y)$ patients with hepatocellular carcinoma.

\begin{tabular}{|c|c|c|c|c|c|c|c|c|c|}
\hline \multirow{2}{*}{$\begin{array}{l}\text { Year/ } \\
\text { author }\end{array}$} & \multirow{2}{*}{$\begin{array}{l}\text { Study } \\
\text { design }\end{array}$} & \multirow{2}{*}{$\begin{array}{l}\text { Definition } \\
\text { of elderly }\end{array}$} & \multirow{2}{*}{$\begin{array}{l}\text { No. of } \\
\text { patients }\end{array}$} & \multirow{2}{*}{$\begin{array}{l}\text { Child } \\
\text { class A }\end{array}$} & \multirow{2}{*}{$\begin{array}{l}\text { Overall } \\
\text { survival }\end{array}$} & \multirow[t]{2}{*}{ ORR } & \multicolumn{2}{|c|}{ TACE } & \multirow{2}{*}{$\begin{array}{l}\text { Hospital stay } \\
\quad \text { (days) }\end{array}$} \\
\hline & & & & & & & Morbidity & Mortality & \\
\hline 2013 & Prospective & $\geq 75$ Years & 38 & $81.5 \%$ & $1 / 2 / 3$-Year, $p=0.19$ & N/A & N/A & N/A & $p=0.19$ \\
\hline Cohen & & $65-75$ Years & 41 & $85.3 \%$ & $74 \% / 37 \% / 31 \%$ & & & & 3.6 \\
\hline et al. (12) & & $<65$ Years & 23 & $82.6 \%$ & $\begin{array}{c}83 \% / 66 \% 48 \% \\
86 \% / 41 \% / 23 \%\end{array}$ & & & & $\begin{array}{c}3.55 \\
3.3\end{array}$ \\
\hline 2014 & Retrospective & $\geq 75$ Years & Y: 84 & $p=0.019$ & $1 / 3$-Year, $p=0.887$ & $p=0.227$ & SAE & Y: 0 & $p=0.053$ \\
\hline Nishigawa & & & E: 66 & Y: $61.9 \%$ & Y: $78.2 \% / 39.3 \%$ & Y: $78.6 \%$ & Y: $6 \%$ & E: $0 \%$ & Y: $12.6 \pm 6.7$ \\
\hline et al. (13) & & & & E: $80.3 \%$ & E: $84.1 \% / 48 \%$ & E: $81.8 \%$ & E: $4.5 \%$ & & E: $10.7 \pm 5.0$ \\
\hline $\begin{array}{l}2014 \text { Liu } \\
\text { et al. (14) }\end{array}$ & $\begin{array}{l}\text { Retrospective } \\
\quad(\mathrm{PSM})\end{array}$ & $\geq 75$ Years & $\begin{array}{l}\text { Y: } 604 \\
\text { E: } 271\end{array}$ & $\begin{array}{l}p<0.001 \\
\text { Y: } 75 \% \\
\text { E: } 86 \%\end{array}$ & $\begin{array}{c}1 / 3 / 5 \text {-Year, } p=0.953 \\
\text { Y: } 79 \% / 57 \% / 42 \% \\
\text { E: } 84 \%, 57 \% / 39 \%\end{array}$ & N/A & N/A & N/A & N/A \\
\hline $\begin{array}{l}2019 \text { Seo } \\
\text { et al. (15) }\end{array}$ & Retrospective & $\geq 75$ Years & E: 208 & E: $80.8 \%$ & $40.20 \pm 2.70$ months & N/A & E: $37.98 \%$ & E: $0.48 \%$ & $7.73 \pm 0.54$ \\
\hline
\end{tabular}

N/A: Not available; ORR: objective response rate; PSM: propensity score matching; SAE: serious adverse event; TACE: transarterial chemoembolization.

for patients with $\mathrm{HCC}$ lesions $<2 \mathrm{~cm}$. For this procedure, under ultrasound guidance, $95 \%$ absolute alcohol is injected into the tumor, resulting in chemical cell dehydration and subsequent tumor necrosis (27). A meta-analysis of randomized controlled trials comparing PEIT and RFA showed better OS, DFS, and recurrence in patients undergoing RFA compared to those undergoing PEIT (40, 41). Therefore, PEIT is performed in select cases when thermal ablation is not feasible (27). Although PEIT seems to be less effective than RFA, and multiple sessions are needed for large tumors, this approach has the advantage of avoiding the heat-sink effect (27). In a study comparing the efficacy and safety of PEIT in elderly patients with HCC (aged >70 years), the 1-, 3-, and 5-year survival rates were comparable to those for younger patients (elderly patients: $83.1 \%, 51.6 \%$, and $27.4 \%$, respectively; younger patients: $90.1 \%, 65 \%$, and $40 \%$, respectively; $p=0.022$ ). Moreover, the 1-, 3-, and 5-year HCC recurrence rates were also similar (elderly patients: $33.1 \%, 56 \%$, and $58.6 \%$, respectively; younger patients: $26.5 \%, 49.8 \%$, and $59.9 \%$, respectively; $p=0.828$ ) (42).

In summary, even though PEIT is not currently performed and has been replaced by newer ablative therapies, it can be safely and effectively performed in patients with HCC lesions $<2 \mathrm{~cm}$ when RFA is technically not feasible or when there is a risk of the heat-sink effect in elderly patients.

Microwave ablation. Microwave ablation uses highfrequency microwave energy (electromagnetic field) to kill cancer cells. Microwave ablation is known to be more effective than RFA in inducing higher intra-tumoral temperature, greater tumor ablation volume, and faster ablation times, and it has a better convection profile than
RFA. However, complications such as vessel damage and liver abscess can develop at a rate of 2-3\% (43).

Microwave ablation is usually performed for tumors larger than $3 \mathrm{~cm}$ or when the tumor is difficult to access by RFA. Adverse events of microwave ablation treatment occurred in fewer than $2.9 \%$ of patients, and included liver failure, bleeding, infection, abscess, intercostal nerve injury, bile duct stenosis, organ injury, and pneumothorax (44). A large study from China reported outcomes after microwave ablation treatment in 1,007 patients with primary HCC. The 1- and 5-year survival rates were $91.2 \%$ and $59.8 \%$, respectively. Subgroup analysis of the study indicated a 5-year survival rate of $29-68.6 \%$ for those with lesions $>5 \mathrm{~cm}(45,46)$. A recent meta-analysis comparing RFA and microwave ablation therapy showed similar trends of complete response and local recurrence, with lower local recurrence rates in those with larger nodules treated with microwave ablation therapy, and a lower 3-year survival rate, without statistical significance, compared to RFA. Major complications of microwave treatment occurred more frequently than with RFA (47).

One study that reported clinical outcomes after microwave ablation suggested this treatment option is safe and effective for older patients with HCC (>65 years) (48). However, as far as we are aware, there are no data on microwave ablation treatment in elderly patients with HCC aged 75 years or older. Large, prospective, and randomized studies are warranted for the evaluation of efficacy and safety of microwave ablation treatment in elderly patients with HCC.

In summary, the data regarding efficacy and safety of microwave ablation treatment in elderly patients with $\mathrm{HCC}$ is inadequate, and therefore further studies are needed. 
in vivo $33: 1411-1420(2019)$

Table V. Summary of sorafenib data in elderly $(E)$ and young $(Y)$ patients with hepatocellular carcinoma (all studies were retrospective).

\begin{tabular}{|c|c|c|c|c|c|c|c|c|}
\hline $\begin{array}{l}\text { Year/ } \\
\text { author }\end{array}$ & $\begin{array}{l}\text { Definition } \\
\text { of elderly }\end{array}$ & $\begin{array}{c}\text { No of } \\
\text { patients }\end{array}$ & $\begin{array}{l}\text { Overall } \\
\text { survival }\end{array}$ & Toxicity & $\begin{array}{l}\text { Dose } \\
\text { reduction }\end{array}$ & Discontinuation & $\begin{array}{c}\text { Median medication } \\
\text { duration (months) }\end{array}$ & $\begin{array}{l}\text { Major } \\
\text { finding }\end{array}$ \\
\hline $\begin{array}{l}2011 \text { Morimoto } \\
\text { et al. (16) }\end{array}$ & $\geq 75$ Years & $\begin{array}{l}\text { Y: } 52 \\
\text { E: } 24\end{array}$ & $\begin{array}{c}p=0.022 \\
\text { Higher in } \\
\text { younger }\end{array}$ & $\begin{array}{c}\mathrm{Gr} \geq 3, p=0.420 \\
\mathrm{Y}: 44.2 \% \\
\mathrm{E}: 54.2 \%\end{array}$ & $\begin{array}{l}\text { Y: } 23.1 \% \\
\text { E: } 50 \%\end{array}$ & $\begin{array}{l}\text { Y: } 42.3 \% \\
\text { E: } 33.3 \%\end{array}$ & $\begin{array}{l}\text { Y: } 1.9 \\
\text { E: } 1.4\end{array}$ & $\begin{array}{l}\text { Similar safety } \\
\text { and efficacy, } \\
\text { more frequent } \\
\text { anorexia in elderly }\end{array}$ \\
\hline $\begin{array}{l}2013 \text { Montella } \\
\text { et al. (17) }\end{array}$ & $\geq 70($ Median=76) & $\mathrm{E}: 60$ & $\begin{array}{c}\mathrm{E}: 10 \\
(95 \% \mathrm{CI}= \\
5.0-14.9)\end{array}$ & N/A & E: $81.7 \%$ & N/A & E: 5 & $\begin{array}{l}\text { Reduced dose of } \\
\text { sorafenib can } \\
\text { be safely used }\end{array}$ \\
\hline $\begin{array}{l}2014 \text { Jo } \\
\text { et al. (18) }\end{array}$ & $\geq 80($ Median $=71)$ & $\begin{array}{l}\text { Y: } 161 \\
\text { E: } 24\end{array}$ & $\begin{array}{l}p>0.05 \\
Y: 10.5 \\
E: 11.7\end{array}$ & $\begin{array}{c}\mathrm{Gr} \geq 3, p>0.05 \\
\mathrm{Y}: 24.2 \% \\
\mathrm{E}: 12.5 \%\end{array}$ & $\begin{array}{c}\text { Y: } 32.9 \% \\
\text { E: } 75 \%\end{array}$ & $\begin{array}{l}\text { Y: } 86 \% \\
\text { E: } 83 \%\end{array}$ & $\begin{array}{l}\text { Y: } 2.7 \\
\text { E: } 2.3\end{array}$ & $\begin{array}{l}\text { Similar safety } \\
\text { and efficacy }\end{array}$ \\
\hline $\begin{array}{l}2017 \text { Ziogas } \\
\text { et al. (19) }\end{array}$ & $\geq 75($ Median=79) & $\begin{array}{l}\text { Y: } 151 \\
\text { E: } 39\end{array}$ & $\begin{array}{c}p=0.360 \\
\mathrm{Y}: 7.1 \\
\mathrm{E}: 10.4\end{array}$ & $\begin{array}{c}\mathrm{Gr} \geq 3, p=0.224 \\
\mathrm{Y}: 28 \% \\
\mathrm{E}: 18 \%\end{array}$ & $\begin{array}{c}p>0.05 \\
\text { Y: } 37.9 \% \\
\text { E: } 41.0 \%\end{array}$ & $\begin{array}{l}p=0.568 \\
\text { Y: } 34.4 \% \\
\text { E: } 28.2 \%\end{array}$ & $\begin{array}{c}\mathrm{Y}: 3(95 \% \\
\mathrm{CI}=2.5-3.9) \\
\mathrm{E}: 5.1(3.1-7.1)\end{array}$ & $\begin{array}{l}\text { Similar safety } \\
\text { and efficacy }\end{array}$ \\
\hline $\begin{array}{l}2017 \text { Williet } \\
\text { et al. }(20)\end{array}$ & $\geq 75($ Median=75) & E: 51 & $\begin{array}{c}\text { E: } 15 \\
(95 \% \mathrm{CI}: \\
10-27)\end{array}$ & $\begin{array}{c}\mathrm{Gr} \geq 3 \\
\mathrm{E}: 60.8 \%\end{array}$ & E: $37.2 \%$ & E: $60.8 \%$ & $\mathrm{E}: 3(\mathrm{IQR}=1.4-6.3)$ & $\begin{array}{l}\text { Poor tolerance } \\
\geq 80 \text { years } \\
\text { Poor OS } \\
\geq 85 \text { years }\end{array}$ \\
\hline
\end{tabular}

CI: Confidence interval; Gr: grade; IQR: interquartile range; OS: overall survival.

\section{Palliative Therapy}

Transarterial chemoembolization. TACE is the most widely performed treatment method for unresectable HCC. Two randomized controlled trials and one meta-analysis demonstrated improved OS for patients with intermediatestage HCC (49-51).

In the past, old age was considered a contraindication for TACE (52). However, recent data suggest that TACE is safe and effective for elderly patients $(26,53-55)$ (Table IV). The OS rates for elderly and younger patients were reportedly similar $(53,55)$. Moreover, TACE-associated morbidity in elderly patients was similar to that in younger patients. In addition, mortality was very low $(0-0.48 \%)$ in patients undergoing this procedure $(26,55)$.

In summary, TACE is a safe and effective treatment modality for elderly patients with intermediate HCC.

Targeted therapy. Sorafenib: Sorafenib is an oral multi-target tyrosine kinase inhibitor [vascular endothelial growth factor (VEGFR) -1, -2 and -3, and platelet-derived growth factor receptor (PDGFR)-beta] and targets the RAF/MEK/ERK pathways, which inhibit tumor cell proliferation and angiogenesis and induce tumor cell apoptosis (56). Sorafenib is generally indicated for patients with BCLC stage C or intermediate $\mathrm{HCC}$ not eligible for or who experienced failure of locoregional therapies for Child- Pugh Class A liver disease (57).

This drug is effective and safe, as demonstrated in the SHARP trial (58) and Asia-Pacific (AP) trial (59). In the
SHARP trial, sorafenib significantly improved the median OS compared to placebo (10.7 vs. 7.9 months; hazard ratio $0.69,95 \% \mathrm{CI}=0.55-0.87)$ (58). In the AP trial, sorafenib significantly improved the median OS compared to placebo (6.5 vs. 4.2 months, hazard ratio $=0.68,95 \%$ confidence intervaI $=0.5-0.93)$ (59). Common adverse events of sorafenib are hand-foot skin reaction, diarrhea, fatigue, anorexia, hypertension, and fatigue. The rates of treatment-related adverse events leading to dose reduction and discontinuation were $26 \%$ and $38 \%$ in the SHARP trial, and $30.9 \%$ and $19.5 \%$ in the AP trial, respectively $(58,59)$.

Although there are limited data regarding this drug in elderly patients with $\mathrm{HCC}$, most studies suggest that survival gain and severe adverse events are similar to those observed in non-elderly patients with $\operatorname{HCC}(60,61)$. However, one study suggested that such events might occur more frequently in elderly patients with HCC than in non-elderly patients (62). Therefore, careful monitoring of sorafenib toxicity is needed. Other studies also suggested reduced doses of this drug should be used cautiously in elderly patients (63) (Table V).

In summary, the efficacy and safety of sorafenib in elderly patients is similar to those in non-elderly patients with $\mathrm{HCC}$, and careful monitoring of sorafenib toxicity is needed.

Lenvatinib: One of the other first-line treatments for advanced HCC is lenvatinib, a multi-kinase inhibitor (VEGFR, and PDGFR, as well as the RET pathway). Indications for lenvatinib are similar to those of sorafenib (64).

The efficacy lenvatinib was highlighted in the REFLECT trial, an international, multicenter, randomized, open label, phase III trial. Based on the results of this trial, the effect of 
lenvatinib on OS was statistically confirmed to be non-inferior to sorafenib in patients with unresectable HCC. The adverse events of lenvatinib included hypertension, diarrhea, anorexia, weight loss, fatigue, hand-foot skin reaction, dysphonia, proteinuria, and hypothyroidism. The discontinuation rates of these drugs were reported to be similar (lenvatinib: $13 \% \mathrm{vs}$. sorafenib: $9 \%$ ). The OS of patients receiving lenvatinib was not inferior to that for those receiving sorafenib; however, the time to progression, objective response rate, and PFS are reported to be better than those associated with sorafenib (64).

There are no data regarding the efficacy and safety of lenvatinib in elderly patients with HCC. However, in the subgroup analysis in the REFLECT trial, 58 patients (12\%) were categorized as elderly ( $>65$ years). The median OS and PFS in patients receiving lenvatinib and sorafenib were comparable (64). Therefore, the efficacy and safety of lenvatinib in elderly patients with HCC may be similar to what is observed with sorafenib. However, data on lenvatinib for patients over 75 years of age with $\mathrm{HCC}$ is scarce, and further large-scale and prospective studies will be needed.

\section{Conclusion}

Compared to younger patients with HCC, elderly patients were more likely to have $\mathrm{HCV}$ infection, or be negative for $\mathrm{HBV}$ and $\mathrm{HCV}$ infection, be female, have limited liver tissue fibrosis, and have fewer HCC nodules.

Regarding treatment modalities, RFA may be feasible in the very early stages of HCC, and surgical resection in very highly selected patients may also be feasible, although only in the early stages. TACE may be safe and effective for patients with intermediate HCC, and sorafenib may be feasible in select elderly patients with advanced HCC. Prospective randomized trials are needed to establish the optimal treatment strategy in elderly patients with HCC.

\section{Authors' Contributions}

Study concept and design: JCH, CSK, KHJ; data acquisition: JCH, $\mathrm{CE}, \mathrm{CHA}$; drafting of the article: $\mathrm{CE}, \mathrm{CHA}$; critical revision of the article for important intellectual content: JCH, KHJ, CSK, JSB; obtained funding: JCH, KHJ. All Authors approved the final draft of the article submitted to the journal.

\section{Conflicts of interest}

None.

\section{References}

1 Aapro MS, Kohne CH, Cohen HJ and Extermann M: Never too old? Age should not be a barrier to enrollment in cancer clinical trials. Oncologist 10(3): 198-204, 2005. PMID: 15793223. DOI: 10.1634/theoncologist.10-3-198
2 Global Burden of Disease Liver Cancer C, Akinyemiju T, Abera $\mathrm{S}$, Ahmed M, Alam N, Alemayohu MA, Allen C, Al-Raddadi R, Alvis-Guzman N, Amoako Y, Artaman A, Ayele TA, Barac A, Bensenor I, Berhane A, Bhutta Z, Castillo-Rivas J, Chitheer A, Choi JY, Cowie B, Dandona L, Dandona R, Dey S, Dicker D, Phuc H, Ekwueme DU, Zaki MS, Fischer F, Furst T, Hancock J, Hay SI, Hotez P, Jee SH, Kasaeian A, Khader Y, Khang YH, Kumar A, Kutz M, Larson H, Lopez A, Lunevicius R, Malekzadeh R, McAlinden C, Meier T, Mendoza W, Mokdad A, Moradi-Lakeh M, Nagel G, Nguyen Q, Nguyen G, Ogbo F, Patton G, Pereira DM, Pourmalek F, Qorbani M, Radfar A, Roshandel G, Salomon JA, Sanabria J, Sartorius B, Satpathy M, Sawhney M, Sepanlou S, Shackelford K, Shore H, Sun J, Mengistu DT, Topor-Madry R, Tran B, Ukwaja KN, Vlassov V, Vollset SE, Vos T, Wakayo T, Weiderpass E, Werdecker A, Yonemoto N, Younis M, Yu C, Zaidi Z, Zhu L, Murray CJL, Naghavi $M$ and Fitzmaurice $C$ : The burden of primary liver cancer and underlying etiologies from 1990 to 2015 at the global, regional, and national level: Results from the Global Burden of Disease study 2015. JAMA Oncol 3(12): 1683-1691, 2017. PMID: 28983565. DOI: 10.1001/jamaoncol.2017.3055

3 Nishikawa H, Kimura T, Kita R and Osaki Y: Treatment for hepatocellular carcinoma in elderly patients: A literature review. J Cancer 4(8): 635-643, 2013. PMID: 24155775 3805991. DOI: $10.7150 /$ jca.7279

4 El-Serag HB and Rudolph KL: Hepatocellular carcinoma: Epidemiology and molecular carcinogenesis. Gastroenterology 132(7): 2557-2576, 2007. PMID: 17570226. DOI: 10.1053/ j.gastro.2007.04.061

5 Brubaker TH and Powers EA: The stereotype of "old." A review and alternative approach. J Gerontol 31(4): 441-447, 1976. PMID: 774005.

6 Fortner JG and Lincer RM: Hepatic resection in the elderly. Ann Surg 211(2): 141-145, 1990. PMID: 2301993.

7 Hori M, Tanaka M, Ando E, Sakata M, Shimose S, Ohno M, Yutani S, Kuraoka K, Kuromatsu R, Sumie S and Sata M: Longterm outcome of elderly patients (75 years or older) with hepatocellular carcinoma. Hepatol Res 44(9): 975-982, 2014. PMID: 24256493. DOI: 10.1111/hepr.12279

8 Tsujita E, Utsunomiya T, Ohta M, Tagawa T, Matsuyama A, Okazaki J, Yamamoto M, Tsutsui S and Ishida T: Outcome of repeat hepatectomy in patients with hepatocellular carcinoma aged 75 years and older. Surgery 147(5): 696-703, 2010. PMID: 20015526. DOI: $10.1016 /$ j.surg.2009.10.054

9 Okamura Y, Sugiura T, Ito T, Yamamoto Y, Ashida R and Uesaka $\mathrm{K}$ : The short- and long-term outcomes in elderly patients with hepatocellular carcinoma after curative surgery: A case-controlled study with propensity score matching. Eur Surg Res 59(5-6): 380390, 2018. PMID: 30554221. DOI: 10.1159/000494733

10 Oishi K, Itamoto T, Kobayashi T, Oshita A, Amano H, Ohdan $\mathrm{H}$, Tashiro $\mathrm{H}$ and Asahara T: Hepatectomy for hepatocellular carcinoma in elderly patients aged 75 years or more. J Gastrointest Surg 13(4): 695-701, 2009. PMID: 19050982. DOI: 10.1007/s11605-008-0758-6

11 Takahashi H, Mizuta T, Kawazoe S, Eguchi Y, Kawaguchi Y, Otuka T, Oeda S, Ario K, Iwane S, Akiyama T, Ozaki I and Fujimoto K: Efficacy and safety of radiofrequency ablation for elderly hepatocellular carcinoma patients. Hepatol Res 40(10): 997-1005, 2010. PMID: 20887335. DOI: 10.1111/j.1872034X.2010.00713.x 
12 Tsujita E, Utsunomiya T, Yamashita Y, Ohta M, Tagawa T, Matsuyama A, Okazaki J, Yamamoto M, Tsutsui S and Ishida T: Outcome of hepatectomy in hepatocellular carcinoma patients aged 80 years and older. Hepatogastroenterology 59(117): 15531555, 2012. PMID: 22683972. DOI: 10.5754/hge09485

13 Randall HB, Cao S and de Vera ME: Transplantation in elderly patients. Arch Surg 138(10): 1089-1092, 2003. PMID: 14557125. DOI: $10.1001 /$ archsurg.138.10.1089

14 Hung AK and Guy J: Hepatocellular carcinoma in the elderly: Meta-analysis and systematic literature review. World J Gastroenterol 21(42): 12197-12210, 2015. PMID: 26576104. DOI: $10.3748 /$ wjg.v21.i42.12197

15 Kinoshita A, Koike $\mathrm{K}$ and Nishino H: Clinical features and prognosis of elderly patients with hepatocellular carcinoma not indicated for surgical resection. Geriatr Gerontol Int 17(2): 189201, 2017. PMID: 26847184. DOI: 10.1111/ggi.12747

16 Tsukioka G, Kakizaki S, Sohara N, Sato K, Takagi H, Arai H, Abe T, Toyoda M, Katakai K, Kojima A, Yamazaki Y, Otsuka T, Matsuzaki Y, Makita F, Kanda D, Horiuchi K, Hamada T, Kaneko M, Suzuki H and Mori M: Hepatocellular carcinoma in extremely elderly patients: An analysis of clinical characteristics, prognosis and patient survival. World J Gastroenterol 12(1): 4853, 2006. PMID: 16440416.

17 Yasui K, Hashimoto E, Tokushige K, Koike K, Shima T, Kanbara Y, Saibara T, Uto H, Takami S, Kawanaka M, Komorizono Y, Okanoue T and Japan NASH Study Group: Clinical and pathological progression of non-alcoholic steatohepatitis to hepatocellular carcinoma. Hepatol Res 42(8): 767-773, 2012. PMID: 22487102. DOI: 10.1111/j.1872-034X. 2012.00986.x

18 Honda T, Miyaaki H, Ichikawa T, Taura N, Miuma S, Shibata H, Isomoto $\mathrm{H}$, Takeshima $\mathrm{F}$ and Nakao K: Clinical characteristics of hepatocellular carcinoma in elderly patients. Oncol Lett 2(5): 851-854, 2011. PMID: 22866139. DOI: 10.3892/ol.2011.359

19 Isokawa O, Suda T, Aoyagi Y, Kawai H, Yokota T, Takahashi T, Tsukada K, Shimizu T, Mori S, Abe Y, Suzuki Y, Nomoto M, Mita Y, Yanagi M, Igarashi $\mathrm{H}$ and Asakura H: Reduction of telomeric repeats as a possible predictor for development of hepatocellular carcinoma: Convenient evaluation by slot-blot analysis. Hepatology 30(2): 408-412, 1999. PMID: 10421648. DOI: $10.1002 /$ hep.510300211

20 Kaibori M, Matsui K, Ishizaki M, Saito T, Kitade H, Matsui Y and Kwon AH: Hepatic resection for hepatocellular carcinoma in the elderly. J Surg Oncol 99(3): 154-160, 2009. PMID: 19123236. DOI: $10.1002 /$ jso.21221

21 Shirabe K, Kajiyama K, Harimoto N, Gion T, Tsujita E, Abe T, Wakiyama S, Nagaie T and Maehara Y: Early outcome following hepatic resection in patients older than 80 years of age. World J Surg 33(9): 1927-1932, 2009. PMID: 19603226. DOI: 10.1007/ s00268-009-0122-3

22 Nishikawa H, Osaki Y, Iguchi E, Koshikawa Y, Ako S, Inuzuka T, Takeda H, Nakajima J, Matsuda F, Sakamoto A, Henmi S, Hatamaru K, Ishikawa T, Saito S, Nasu A, Kita R and Kimura $\mathrm{T}$ : The effect of long-term supplementation with branched-chain amino acid granules in patients with hepatitis $\mathrm{C}$ virus-related hepatocellular carcinoma after radiofrequency thermal ablation. J Clin Gastroenterol 47(4): 359-366, 2013. PMID: 23090049. DOI: $10.1097 / \mathrm{MCG} .0 \mathrm{~b} 013 \mathrm{e} 31826 \mathrm{be} 9 \mathrm{ad}$

23 Marrero JA, Fontana RJ, Su GL, Conjeevaram HS, Emick DM and Lok AS: Nafld may be a common underlying liver disease in patients with hepatocellular carcinoma in the United States. Hepatology 36(6): 1349-1354, 2002. PMID: 12447858. DOI: 10.1053 /jhep.2002.36939

24 Miki D, Aikata H, Uka K, Saneto H, Kawaoka T, Azakami T, Takaki S, Jeong SC, Imamura M, Kawakami Y, Takahashi S, Itamoto $\mathrm{T}$, Asahara $\mathrm{T}$, Arihiro $\mathrm{K}$ and Chayama $\mathrm{K}$ : Clinicopathological features of elderly patients with hepatitis $\mathrm{C}$ virus-related hepatocellular carcinoma. J Gastroenterol 43(7): 550557, 2008. PMID: 18648742. DOI: 10.1007/s00535-008-2194-5

25 Ide T, Miyoshi A, Kitahara K and Noshiro H: Prediction of postoperative complications in elderly patients with hepatocellular carcinoma. J Surg Res 185(2): 614-619, 2013. PMID: 23932657. DOI: 10.1016/j.jss.2013.07.016

26 Seo JH, Kim DH, Cho E, Jun CH, Park SY, Cho SB, Park CH, Kim HS, Choi SK and Rew JS: Characteristics and outcomes of extreme elderly patients with hepatocellular carcinoma in South Korea. In Vivo 33(1): 145-154, 2019. PMID: 30587615. DOI: 10.21873/invivo.11451

27 European Association for the Study of the Liver. Electronic address eee and European Association for the Study of the L: EASL Clinical Practice Guidelines: Management of hepatocellular carcinoma. J Hepatol 69(1): 182-236, 2018. PMID: 29628281. DOI: 10.1016/j.jhep.2018.03.019

28 Yamada S, Shimada M, Miyake H, Utsunomiya T, Morine Y, Imura S, Ikemoto T, Mori H, Hanaoka J, Iwahashi S and Saito Y: Outcome of hepatectomy in super-elderly patients with hepatocellular carcinoma. Hepatol Res 42(5): 454-458, 2012. PMID: 22295877. DOI: 10.1111/j.1872-034X.2011.00952.x

29 Nishikawa H, Arimoto A, Wakasa T, Kita R, Kimura T and Osaki Y: Surgical resection for hepatocellular carcinoma: Clinical outcomes and safety in elderly patients. Eur J Gastroenterol Hepatol 25(8): 912-919, 2013. PMID: 23470356. DOI: $10.1097 / \mathrm{MEG} .0 \mathrm{~b} 013 \mathrm{e} 32835 \mathrm{fa} 668$

30 Ueno M, Hayami S, Tani M, Kawai M, Hirono S and Yamaue $\mathrm{H}$ : Recent trends in hepatectomy for elderly patients with hepatocellular carcinoma. Surg Today 44(9): 1651-1659, 2014. PMID: 24091862. DOI: 10.1007/s00595-013-0739-6

31 Kishida N, Hibi T, Itano O, Okabayashi K, Shinoda M, Kitago M, Abe Y, Yagi H and Kitagawa Y: Validation of hepatectomy for elderly patients with hepatocellular carcinoma. Ann Surg Oncol 22(9): 3094-3101, 2015. PMID: 25582743. DOI: 10.1245/ s10434-014-4350-x

32 Santambrogio R, Barabino M, Scifo G, Costa M, Giovenzana M and Opocher E: Effect of age (over 75 years) on postoperative complications and survival in patients undergoing hepatic resection for hepatocellular carcinoma. J Gastrointest Surg 21(4): 657-665, 2017. PMID: 28083840. DOI: 10.1007/s11605-0163354-1

$33 \mathrm{Wu} \mathrm{FH}$, Shen $\mathrm{CH}$, Luo SC, Hwang JI, Chao WS, Yeh HZ, Jan YG, Yen Y, Cheng SB, Wu CC, Lin YL and P'Eng FK: Liver resection for hepatocellular carcinoma in oldest old patients. World J Surg Oncol 17(1): 1, 2019. PMID: 30606220. DOI: 10.1186/s12957-018-1541-0

34 Poulou LS, Botsa E, Thanou I, Ziakas PD and Thanos L: Percutaneous microwave ablation $v s$. radiofrequency ablation in the treatment of hepatocellular carcinoma. World J Hepatol 7(8): 1054-1063, 2015. PMID: 26052394. DOI: 10.4254/wjh. v7.i8.1054

35 Shiina S, Tateishi R, Arano T, Uchino K, Enooku K, Nakagawa H, Asaoka Y, Sato T, Masuzaki R, Kondo Y, Goto T, Yoshida H, 
Omata $\mathrm{M}$ and Koike $\mathrm{K}$ : Radiofrequency ablation for hepatocellular carcinoma: 10-Year outcome and prognostic factors. Am J Gastroenterol 107(4): 569-577, 2012. PMID: 22158026. DOI: 10.1038/ajg.2011.425

36 Chen MS, Li JQ, Zheng Y, Guo RP, Liang HH, Zhang YQ, Lin $\mathrm{XJ}$ and Lau WY: A prospective randomized trial comparing percutaneous local ablative therapy and partial hepatectomy for small hepatocellular carcinoma. Ann Surg 243(3): 321-328, 2006. PMID: 16495695. DOI: 10.1097/01.sla.00002014 80.655 $19 . \mathrm{b} 8$

37 Huang J, Yan L, Cheng Z, Wu H, Du L, Wang J, Xu Y and Zeng $Y$ : A randomized trial comparing radiofrequency ablation and surgical resection for HCC conforming to the Milan criteria. Ann Surg 252(6): 903-912, 2010. PMID: 21107100. DOI: 10.1097/ SLA.0b013e3181efc656

38 Hiraoka A, Michitaka K, Horiike N, Hidaka S, Uehara T, Ichikawa S, Hasebe A, Miyamoto Y, Ninomiya T, Sogabe I, Ishimaru Y, Kawasaki H, Koizumi Y, Hirooka M, Yamashita Y, Abe M, Hiasa Y, Matsuura B and Onji M: Radiofrequency ablation therapy for hepatocellular carcinoma in elderly patients J Gastroenterol Hepatol 25(2): 403-407, 2010. PMID: 19929922. DOI: $10.1111 / \mathrm{j} .1440-1746.2009 .06037 . x$

39 Nishikawa H, Osaki Y, Iguchi E, Takeda H, Ohara Y, Sakamoto A, Hatamaru K, Henmi S, Saito S, Nasu A, Kita R and Kimura T: Percutaneous radiofrequency ablation for hepatocellular carcinoma: Clinical outcome and safety in elderly patients. J Gastrointestin Liver Dis 21(4): 397-405, 2012. PMID: 23256123.

40 Germani G, Pleguezuelo M, Gurusamy K, Meyer T, Isgro G and Burroughs AK: Clinical outcomes of radiofrequency ablation, percutaneous alcohol and acetic acid injection for hepatocelullar carcinoma: A meta-analysis. J Hepatol 52(3): 380-388, 2010. PMID: 20149473. DOI: 10.1016/j.jhep.2009.12.004

41 Cho YK, Kim JK, Kim MY, Rhim H and Han JK: Systematic review of randomized trials for hepatocellular carcinoma treated with percutaneous ablation therapies. Hepatology 49(2): 453459, 2009. PMID: 19065676. DOI: 10.1002/hep.22648

42 Teratani $\mathrm{T}$, Ishikawa $\mathrm{T}$, Shiratori $\mathrm{Y}$, Shiina S, Yoshida $\mathrm{H}$, Imamura $\mathrm{M}$, Obi $\mathrm{S}$, Sato $\mathrm{S}$, Hamamura $\mathrm{K}$ and Omata $\mathrm{M}$ : Hepatocellular carcinoma in elderly patients: Beneficial therapeutic efficacy using percutaneous ethanol injection therapy. Cancer 95(4): 816-823, 2002. PMID: 12209726. DOI: 10.1002/cncr.10735

43 Cavagnaro M, Amabile C, Cassarino S, Tosoratti N, Pinto R and Lopresto V: Influence of the target tissue size on the shape of $e x$ vivo microwave ablation zones. Int J Hyperthermia 31(1): 48-57, 2015. PMID: 25677838. DOI: 10.3109/02656736.2014.997312

44 Liang P, Yu J, Lu MD, Dong BW, Yu XL, Zhou XD, Hu B, Xie MX, Cheng W, He W, Jia JW and Lu GR: Practice guidelines for ultrasound-guided percutaneous microwave ablation for hepatic malignancy. World J Gastroenterol 19(33): 5430-5438, 2013. PMID: 24023485. DOI: 10.3748/wjg.v19.i33.5430

45 Liang P, Wang Y, Yu X and Dong B: Malignant liver tumors: Treatment with percutaneous microwave ablation - complications among cohort of 1,136 patients. Radiology 251(3): 933-940, 2009. PMID: 19304921. DOI: 10.1148/radiol.2513081740

46 Liang P, Yu J, Yu XL, Wang XH, Wei Q, Yu SY, Li HX, Sun HT, Zhang ZX, Liu HC, Cheng ZG and Han ZY: Percutaneous cooled-tip microwave ablation under ultrasound guidance for primary liver cancer: A multicentre analysis of 1363 treatment- naive lesions in 1007 patients in China. Gut 61(7): 1100-1101, 2012. PMID: 21997552. DOI: 10.1136/gutjnl-2011-300975

47 Facciorusso A, Di Maso M and Muscatiello N: Microwave ablation versus radiofrequency ablation for the treatment of hepatocellular carcinoma: A systematic review and metaanalysis. Int J Hyperthermia 32(3): 339-344, 2016. PMID: 26794414. DOI: $10.3109 / 02656736.2015 .1127434$

48 Shen X, Ma S, Tang X, Wang T, Qi X, Chi J, Wang Z, Cui D, Zhang Y, Li P and Zhai B: Clinical outcome in elderly chinese patients with primary hepatocellular carcinoma treated with percutaneous microwave coagulation therapy (PMCT): A strobecompliant observational study. Medicin 97(35): e11618, 2018. PMID: 30170369. DOI: 10.1097/MD.0000000000011618

49 Llovet JM, Real MI, Montana X, Planas R, Coll S, Aponte J, Ayuso C, Sala M, Muchart J, Sola R, Rodes J, Bruix J and Barcelona Liver Cancer Group: Arterial embolisation or chemoembolisation versus symptomatic treatment in patients with unresectable hepatocellular carcinoma: A randomised controlled trial. Lancet 359(9319): 1734-1739, 2002. PMID: 12049862. DOI: 10.1016/S0140-6736(02)08649-X

50 Lo CM, Ngan H, Tso WK, Liu CL, Lam CM, Poon RT, Fan ST and Wong J: Randomized controlled trial of transarterial lipiodol chemoembolization for unresectable hepatocellular carcinoma. Hepatology 35(5): 1164-1171, 2002. PMID: 11981766. DOI: $10.1053 /$ jhep.2002.33156

51 Camma C, Schepis F, Orlando A, Albanese M, Shahied L, Trevisani F, Andreone P, Craxi A and Cottone M: Transarterial chemoembolization for unresectable hepatocellular carcinoma: Meta-analysis of randomized controlled trials. Radiology 224(1): 47-54, 2002. PMID: 12091661. DOI: 10.1148/radiol.2241 011262

52 Mondazzi L, Bottelli R, Brambilla G, Rampoldi A, Rezakovic I, Zavaglia C, Alberti A and Ideo G: Transarterial oily chemoembolization for the treatment of hepatocellular carcinoma: A multivariate analysis of prognostic factors. Hepatology 19(5): 1115-1123, 1994. PMID: 7513677.

53 Cohen MJ, Bloom AI, Barak O, Klimov A, Nesher T, Shouval $\mathrm{D}$, Levi I and Shibolet O: Trans-arterial chemo-embolization is safe and effective for very elderly patients with hepatocellular carcinoma. World J Gastroenterol 19(16): 2521-2528, 2013. PMID: 23674854. DOI: 10.3748/wjg.v19.i16.2521

54 Liu PH, Hsu CY, Lee YH, Hsia CY, Huang YH, Su CW, Chiou YY, Lin HC and Huo TI: Uncompromised treatment efficacy in elderly patients with hepatocellular carcinoma: A propensity score analysis. Medicine 93(28): e264, 2014. PMID: 25526453. DOI: 10.1097/MD.0000000000000264

55 Nishikawa H, Kita R, Kimura T, Ohara Y, Takeda H, Sakamoto A, Saito S, Nishijima N, Nasu A, Komekado H and Osaki Y: Transcatheter arterial chemoembolization for intermediate-stage hepatocellular carcinoma: Clinical outcome and safety in elderly patients. J Cancer 5(7): 590-597, 2014. PMID: 25057310. DOI: $10.7150 /$ jca. 9413

56 Wilhelm SM, Carter C, Tang L, Wilkie D, McNabola A, Rong H, Chen C, Zhang X, Vincent P, McHugh M, Cao Y, Shujath J, Gawlak S, Eveleigh D, Rowley B, Liu L, Adnane L, Lynch M, Auclair D, Taylor I, Gedrich R, Voznesensky A, Riedl B, Post LE, Bollag G and Trail PA: Bay 43-9006 exhibits broadspectrum oral antitumor activity and targets the RAF/MEK/ERK pathway and receptor tyrosine kinases involved in tumor progression and angiogenesis. Cancer Res 64(19): 7099-7109, 2004. PMID: 15466206. DOI: 10.1158/0008-5472.CAN-04-1443 
57 Kudo M, Ueshima K and Arizumi T: Real-life clinical practice with sorafenib in advanced hepatocellular carcinoma: A singlecenter experience. Dig Dis 30(6): 609-616, 2012. PMID: 23258103. DOI: $10.1159 / 000343091$

58 Llovet JM, Ricci S, Mazzaferro V, Hilgard P, Gane E, Blanc JF, de Oliveira AC, Santoro A, Raoul JL, Forner A, Schwartz M, Porta C, Zeuzem S, Bolondi L, Greten TF, Galle PR, Seitz JF, Borbath I, Haussinger D, Giannaris T, Shan M, Moscovici M, Voliotis D, Bruix $\mathbf{J}$ and SHARP Investigators Study Group: Sorafenib in advanced hepatocellular carcinoma. N Engl J Med 359(4): 378-390, 2008. PMID: 18650514. DOI: 10.1056/ NEJMoa0708857

59 Cheng AL, Kang YK, Chen Z, Tsao CJ, Qin S, Kim JS, Luo R, Feng J, Ye S, Yang TS, Xu J, Sun Y, Liang H, Liu J, Wang J, Tak WY, Pan H, Burock K, Zou J, Voliotis D and Guan Z: Efficacy and safety of sorafenib in patients in the asia-pacific region with advanced hepatocellular carcinoma: A phase III randomised, double-blind, placebo-controlled trial. Lancet Oncol 10(1): 25-34, 2009. PMID: 19095497. DOI: 10.1016/S1470-2045(08)70285-7

60 Jo M, Yasui K, Kirishima T, Shima T, Niimi T, Katayama T, Mori T, Funaki J, Sumida Y, Fujii H, Takami S, Kimura H, Mitsumoto Y, Minami M, Yamaguchi K, Yoshinami N, Mizuno M, Sendo R, Tanaka S, Shintani H, Kagawa K, Okanoue T and Itoh Y: Efficacy and safety of sorafenib in very elderly patients aged 80 years and older with advanced hepatocellular carcinoma. Hepatol Res 44(13): 1329-1338, 2014. PMID: 24528772. DOI: 10.1111/hepr.12308

61 Ziogas DC, Papadatos-Pastos D, Thillai K, Korantzis I, Chowdhury R, Suddle A, O'Grady J, Al-Khadimi G, Allen N, Heaton N, Ross PJ and Sarker D: Efficacy and safety of sorafenib in patients with advanced hepatocellular carcinoma: Age is not a problem. Eur J Gastroenterol Hepatol 29(1): 48-55, 2017. PMID: 27623000. DOI: 10.1097/MEG.0000000000 000739
62 Williet N, Clavel L, Bourmaud A, Verot C, Bouarioua N, Roblin $\mathrm{X}$, Merle P and Phelip JM: Tolerance and outcomes of sorafenib in elderly patients treated for advanced hepatocellular carcinoma. Dig Liver Dis 49(9): 1043-1049, 2017. PMID: 28712860. DOI: 10.1016/j.dld.2017.06.008

63 Montella L, Addeo R, Cennamo G, Vincenzi B, Palmieri R, Sperlongano P, Sperlongano R, Iodice P, Russo P and Del Prete S: Sorafenib in elderly patients with advanced hepatocellular carcinoma: A case series. Oncology 84(5): 265-272, 2013. PMID: 23428832. DOI: 10.1159/000345558

64 Kudo M, Finn RS, Qin S, Han KH, Ikeda K, Piscaglia F, Baron A, Park JW, Han G, Jassem J, Blanc JF, Vogel A, Komov D, Evans TRJ, Lopez C, Dutcus C, Guo M, Saito K, Kraljevic S, Tamai T, Ren M and Cheng AL: Lenvatinib versus sorafenib in first-line treatment of patients with unresectable hepatocellular carcinoma: A randomised phase 3 non-inferiority trial. Lancet 391(10126): 1163-1173, 2018. PMID: 29433850. DOI: 10.1016/ S0140-6736(18)30207-1

65 Morimoto M, Numata K, Kondo M, Hidaka H, Takada J, Shibuya A, Kobayashi S, Ohkawa S, Okuse C, Morita S, Taguri M and Tanaka K: Higher discontinuation and lower survival rates are likely in elderly japanese patients with advanced hepatocellular carcinoma receiving sorafenib. Hepatol Res 41(4): 296-302, 2011. PMID: 21348907. DOI: 10.1111/j.1872-034X.2011.00778.x
Received May 20, 2019

Revised June 19, 2019

Accepted June 20, 2019 